Teologia i Moralność, volumen 16(2021), numer 1(29)

doi: 10.14746/TIM.2021.29.1.10

ORCID 0000-0001-6799-9515

ANDRZEJ BOHDANOWICZ

Uniwersytetu im. Adama Mickiewicza w Poznaniu

Wydział Teologiczny

\title{
Lagodność pastoralna w pracy kapelana szpitalnego w kontekście opieki duchowej nad pacjentem
}

\section{Wstęp}

Choć medycyna XXI wieku zapewnia pacjentowi coraz wyższy poziom diagnostyczny, terapeutyczny oraz lepsze warunki pobytu w szpitalu, to ciągle jest coraz więcej osób, które czują się bezsilne wobec choroby i osamotnione w walce $\mathrm{z}$ wewnętrznymi dylematami, jaki ten stan rodzi. Wydaje się, że większym problemem jest zdiagnozowanie i leczenie cierpienia duchowego niż bólu somatycznego. Chory często pozostaje sam zarówno ze swoim lękiem wywołanym chorobą, jak i z wątpliwościami co do dalszego celu i sensu życia. Obciążeni ponad miarę obowiązkami zawodowymi lekarze i pielęgniarki coraz mniej czasu mogą przeznaczyć na rozmowę z pacjentem, niedotyczącą wprost symptomów choroby.

Źródłem pomocy duchowej dla pacjentów w chorobie może być m.in. obecność kapelana szpitalnego. Wymagania formalne wobec kapelanów są różne $\mathrm{w}$ poszczególnych krajach, co wynika z różnic instytucjonalnych, regionalnych i religijnych. W większości krajów Europy panuje przekonanie, że kapelani powinni być odpowiednio wyszkoleni i przygotowani do świadczenia opieki duchowej nad pacjentami. Placówki ochrony zdrowia zatrudniają zawodowych kapelanów jako specjalistów od opieki duchowej i włączają ich do zespołów interdyscyplinarnych. W Polsce status kapelanów szpitalnych jest nadal nieokreślony, a zatem kwestie związane $\mathrm{z}$ ich obecnością w szpitalach należy rozwiązać systemowo - nie ze względu na Kościół, religię czy kapela- 
nów, ale dla dobra pacjentów, którym w czasie pobytu w szpitalu lub w innej placówce medycznej należy się profesjonalna opieka duchowa.

W niniejszym tekście chcemy spojrzeć na obecne od pierwszych wieków w Kościele działanie duszpasterskie określane terminem benignitas pastoralis ('łagodność pastoralna') i odnieść je do posługi kapelana w ramach opieki duchowej nad pacjentem. Stawiamy tezę, że duszpasterstwo oparte na pastoralnej łagodności powinno mieć zastosowanie w pracy kapelana w szpitalu w odniesieniu do osób chorych, ich rodzin i personelu medycznego oraz być traktowane jako istotny element opieki duchowej. Na początku artykułu przybliżymy kwestię opieki duchowej w medycynie, następnie wyjaśnimy, na czym polega duszpasterstwo oparte na łagodności pastoralnej, aby w końcowej części zwrócić uwagę na implikacje benignitas pastoralis w pracy kapelana szpitalnego.

\section{Opieka duchowa nad pacjentem}

Pracownicy szeroko rozumianej ochrony zdrowia zdają sobie sprawę, że leczenie chorych i opieka nad nimi powinny uwzględniać, iż człowiek jest bytem wielowymiarowym, składającym się ze sfery biologicznej, psychicznej i duchowej. W procesie leczenia wszystkie te składowe osoby ludzkiej należy uwzględnić jako istotne. Oprócz sfery cielesnej (ciało - gr. soma), którą zajmuje się zespół medyczny, pacjent ma bogatą sferę ducha (gr. psyche) - psychikę, której zasadniczymi atrybutami są rozum, wola, pamięć oraz uczucia wyższe. Obszar ludzkiego psyche jest szczególnie istotny dla psychologa, który niejednokrotnie okazuje się bardzo ważnym współpracownikiem lekarza w procesie leczenia: pomaga pacjentowi znaleźć motywację do podjęcia terapii, próbuje odpowiadać na jego pytania egzystencjalne oraz przygotowuje do podjęcia trudnych, życiowych decyzji związanych z sytuacją, w której się znalazł.

W człowieku istnieje jeszcze jedna sfera, nadprzyrodzona, dostrzegalna przez pryzmat wiary: ludzka dusza (pneuma) otwarta na nadprzyrodzoność, pozwalająca wchodzić w relacje z Bogiem. To właśnie ludzka dusza jest obszarem posługi kapelana, opieka nad nią okazuje się równie ważna, jak działania lekarzy i psychologów wobec ciała i psychiki pacjentów. Pracownicy służby zdrowia wiedzą najlepiej, jak wiele wewnętrznej siły można znaleźć u głęboko wierzących chorych. Jednak należy zauważyć, że dzisiejsza wiedza pozwala jednoznacznie stwierdzić, iż opieki duchowej potrzebują także pacjenci, którzy nie wierzą w to, że mają duszę - im również kapelan powinien umieć pomóc.

Wymiar duchowy jest elementem konstytutywnym każdego człowieka, także niewierzącego w Boga, stąd nie może być utożsamiany wyłącznie z re- 
ligijnością. Oba te obszary są ze sobą ściśle powiązane, wzajemnie się przenikają i uzupełniają, ale nie zawsze się pokrywają. Wymiar duchowy „wyraża się w wewnętrznej potrzebie człowieka do ukierunkowania własnego życia i wzrastania poprzez przemianę wewnętrzną, poszukiwaniu szczęścia, realizacji swoich ideałów" (Babicz i Grabowicz 2012, 51). Przejawia się w poszukiwaniu sensu życia, stawianiu szeregu pytań natury egzystencjalnej, takich jak: Skąd pochodzimy, dokąd zmierzamy, czym jest życie, czym jest śmierć, jaki jest sens bólu? Szukamy na nie odpowiedzi, odnosząc się do wyznawanych wartości, które odzwierciedlają wymiar duchowy każdej istoty ludzkiej.

Wyniki badań empirycznych w obszarze opieki duchowej nad pacjentem dowodzą, że każdy pacjent czerpie korzyści z dobrej kondycji duchowej, większość pacjentów ma potrzeby duchowe lub szuka oparcia w religii. Istnieją też pacjenci, którzy podejmują decyzje dotyczące leczenia lub radzą sobie z chorobą i śmiercią, kierując się wiarą i przekonaniami religijnymi (Puchalski 2013, 491-497; Beida et. al. 2017, 157-163; Brożek et. al. 2018, 22-124). Dlatego też postulaty, aby opieka duchowa stanowiła niezbędną część kompleksowej opieki nad pacjentami wydają się uzasadnione. Niestety, nadal w wielu przypadkach sfera duchowa pacjenta jest ignorowana, niezdiagnozowana, nieleczona i niewłączona do całościowego planu opieki medycznej.

Z badań dr Anny Vandenhoeck, specjalistki opieki duchowej w medycynie, kierownika Akademickiego Centrum Teologii Praktycznej na Wydziale Teologii i Religioznawstwa Uniwersytetu Katolickiego w Leuven w Belgii, byłej koordynatorki Europejskiej Sieci Kapelanów w Ochronie Zdrowia (European Network for Health Care Chaplains - ENHCC) czy prof. Christiny M. Puchalski z Waszyngtonu, światowej ekspertki w dziedzinie opieki duchowej nad pacjentem, wynika, że tego rodzaju opieka jest integralnym i komplementarnym elementem holistycznej opieki nad osobą chorą, swoistą „,wartością dodaną”. Jest tak samo ważna jak pomoc stricte medyczna czy psychologiczna, a zatem nie może być traktowana jako „dodatek” w procesie leczenia osoby chorej (Vandenhoeck 2013, 552-557; Puchalski 2006, 150-155).

Lekarze i pozostali pracownicy ochrony zdrowia coraz częściej usiłują spojrzeć na pacjenta holistycznie, uwzględniając w nim współistnienie wzajemnie przenikających się i oddziałujących na siebie trzech sfer: ciała, psychiki i duszy. Mają oni świadomość, że medycyna ma pomagać ludziom chorym, ale jej fundamentalnym zadaniem jest dostrzeganie chorego człowieka, a nie koncentrowanie się wyłącznie na jego chorobie. Doświadczenia północnoamerykańskie i zachodnioeuropejskie pokazują, że dobra opieka duchowa przynosi wymierne korzyści pacjentom, np. zwiększa jakość i skuteczność leczenia oraz odgrywa ogromną rolę w końcowym okresie ich życia. Człowiek jest jedyną istotą na ziemi, która poszukuje sensu życia; jeśli go nie znajduje, traci motywację do walki o życie, często rezygnuje z leczenia i poddaje się - 
wówczas żaden lekarz nie jest w stanie mu pomóc. Potrzebny jest wtedy m.in. kompetentny opiekun duchowy, potrafiący podjąć rozmowę na najtrudniejsze tematy, obejmujące wrażliwy obszar życia duchowego pacjenta, i podnieść go na duchu (Krajnik 2016, 122-124).

Jak już wcześniej wspomnieliśmy, organizacja opieki duszpasterskiej i stopień jej rozwoju są zróżnicowane w różnych krajach europejskich. Wszędzie jednak widać rosnącą profesjonalizację opieki duszpasterskiej, czego przejawem są m.in. powstające stowarzyszenia skupiające kapelanów szpitalnych, w gronie których, obok duchownych, znajdziemy także osoby świeckie. Wynika to z przekonania, że osoby pracujące wśród chorych powinny mieć odpowiednie profesjonalne przygotowanie w zakresie oceny potrzeb duchowych pacjenta, gdyż ma on prawo oczekiwać kontaktu z odpowiednio przygotowanym personelem. Jak piszą Urs Winter-Pfändler i Camille Morgenthaler (2011, 146), „W niektórych krajach europejskich, takich jak Holandia, Szwajcaria, Niemcy czy Belgia, opieka duszpasterska jest uwzględniona w regulacjach prawnych wynikających z prawa do wolności wyznania”.

Wiemy dzisiaj z naukową pewnością, że dobra opieka duchowa leży w najlepiej rozumianym interesie pacjenta. Staje się coraz bardziej oczywiste, że aby osiągnąć ten cel, należy z empatią i szacunkiem podchodzić do pacjenta, rozmawiać z nim i poznawać jego potrzeby, obawy, marzenia i nadzieje. Ważne jest, aby wiedzieć, kim jest pacjent, a nie tylko, na co choruje (Szparkowska 2013). Stąd nie bez przyczyny rozmowę uznaje się za serce medycyny. Przypatrzmy się, czy łagodność pastoralna w odniesieniu do pracy kapelana szpitalnego może być konstruktywną propozycją, implikującą lepsze jakościowo i bardziej ewangeliczne spotkanie z człowiekiem chorym i cierpiącym. Czy posługa kapelana w szpitalu, w duchu benignitas pastoralis, może się stać nową jakością i stylem duszpasterstwa, szczególnym dobrodziejstwem dla osoby chorej i środowiska, w którym przebywa? Aby odpowiedzieć na te pytania, analizie poddane zostanie najpierw duszpasterstwo prowadzone $\mathrm{w}$ duchu łagodności pastoralnej.

\section{Duszpasterstwo w duchu benignitas pastoralis}

Łaciński termin benignitas pastoralis oznacza łagodność pastoralną i odnosi się do naśladowania w duszpasterstwie samego Boga, który w Jezusie Chrystusie zamieszkał wśród ludzi, chcąc im ukazać miłosierne oblicze Ojca (Hajduk 2018). Tak ukazują Go również dobrze znane biblijne przypowieści o miłosiernym ojcu (Łk 15, 11-32), zagubionej owcy (Łk 15,1-7), kobiecie pochwyconej na cudzołóstwie (J 8, 1-11) czy miłosiernym Samarytaninie (Łk 10, 30-37). Łagodność pastoralna polega na podchodzeniu do ludzi słabych i za- 
gubionych bez osądzania czy potępiania i zachęcaniu ich do nawrócenia. W Biblii termin ten oznacza współczucie i serdeczność względem drugiego człowieka oraz pocieszanie i pomaganie mu. „Bóg w swoim Synu, Jezusie Chrystusie wychodzi ku człowiekowi, aby objawić swą odkupieńczą miłość, której szczególnymi adresatami są grzesznicy, ubodzy, odrzuceni, chorzy i cierpiący" (Hajduk 2017, 182). Ten ruch Boga w kierunku człowieka, Jego zbawcza inicjatywa polega na „zniżaniu się” Bożej Mądrości ku ludziom (Sobór Watykański II 1965, 13). To zejście Boga uwidacznia się szczególnie w Jezusie Chrystusie, który, podobnie do lekarza idącego do chorych, zstępuje na ziemię w celu przywrócenia zdrowia człowiekowi cierpiącemu i zbawienia go (Benedykt XVI 2005, 12).

O miłosierdziu Bożym, niosącym odkupienie grzesznemu człowiekowi, wypowiadał się m.in. św. Alfons Maria de Liguori (1696-1787) „wzywający duszpasterzy do przejścia od rygoryzmu, czyli odrzucenia grzesznika, do jego akceptacji, tj. łagodności pastoralnej” (Vidal 1996, 419). Jego zdaniem, surowość w podejściu do człowieka nie przyczyni się do jego zbawienia. Patron moralistów, pełen empatii i współczucia dla grzeszników, wzywając wszystkich duchownych do naśladowania Chrystusa, zalecał duszpasterzom postawę pełną łagodności. Zachęcał, aby „naśladując Jezusa jako pełnego współczucia lekarza, kapłan nie okazywał nikomu niechęci ani zniecierpliwienia, gdyż mógłby w ten sposób zranić człowieka" (Hajduk 2017, 185). Według świętego, tylko dobroć okazana grzesznikowi może prowadzić do jego wewnętrznej odnowy, czyli metanoi, i być początkiem nowego życia w Chrystusie.

Kolejną postacią, która zwracała uwagę na praktykowanie współczucia i solidarności z grzesznikiem, był Henri J.M. Nouwen (1932-1996) - katolicki ksiądz, wykładowca kilku instytutów i uczelni teologicznych, służący przez ostatnie lata swojego życia ludziom upośledzonym. W swoich pismach oraz w pracy kapłańskiej ukazywał duszpasterzom „,konieczność myślenia, mówienia oraz działania w imię i w duchu Jezusa, który przez swoje wcielenie ogołocił się, aby zjednoczyć się z człowiekiem i wskazać mu drogę prowadzącą do życia wiecznego" (Hajduk 2017, 185). Przekonywał, że każdy duszpasterz musi być świadomy, że „źródłem jego przepowiadania i aktywności jest sam Bóg - miłosierny i litościwy, którego ludzkie nieszczęścia skłaniają do interwencji. Bóg, który z miłości pochyla się nad człowiekiem, aby dzielić jego radości i bóle oraz bronić i strzec go przed złem. Takiego Boga objawia ludziom Chrystus, Syn Boży, ucieleśniający miłosierdzie Ojca niebieskiego w słowach i czynach. Utożsamiając się z człowiekiem, staje się On odrzuconym dla odrzuconych, głodnym dla głodnych, chorym dla chorych, aby zakomunikować ludziom Bożą czułość i dobroć” (Nouwen i McNeill i Morrison 1997, 16-17). Zdaniem Nouwena, ,duszpasterze powinni okazywać bliźnim to samo miłosierdzie, z którym Bóg zwraca się ku ludziom w Jezusie Chrystusie. Punktem 
wyjścia dla posługi duszpasterskiej powinna być znajomość przez duszpasterzy własnego wnętrza i niedoskonałości. Doświadczenie kruchości własnego istnienia skłania do zanurzenia się w miłości Boga, uzdalniającej do ofiarnej służby bliźnim. Każdy, kto jest ogarnięty Bożą miłością nie może czynić nic innego, jak służyć potrzebującym” (Hajduk 2015, 186).

Jak widać, nawet pobieżne omówienie zagadnienia benignitas pastoralis pokazuje, że wiele z jej przymiotów można odnieść explicite do posługi kapelana w szpitalu. Przyjrzyjmy się zatem bliżej takim aspektom łagodności pastoralnej, jak: jej personalistyczny charakter, wartość pedagogiczna, oddziaływanie terapeutyczne oraz ewangeliczna siła, odnosząc je do pracy kapelana.

\section{Lagodność pastoralna w pracy kapelana szpitalnego}

Obecnie można zaobserwować w świecie trend zmierzający do podporządkowania jednostki ekonomii - człowiek jest postrzegany głównie jako generujący określony dochód. W centrum jest zysk, on jest najważniejszy i często staje się punktem wyjścia do wyznaczania standardów działania. Istnieje niebezpieczeństwo, że również medycyna zostanie podporządkowana takim trendom w odniesieniu do osób chorych, przebywających w szpitalach czy domach opieki społecznej. Jeśli wartość człowieka będziemy mierzyć jego wkładem w pomnażanie dobrobytu, to w sytuacji choroby czy starości staniemy się obywatelami bezużytecznymi, obciążającymi budżet państwa.

W takim kontekście „miłosierdzie pastoralne wydaje się stanowić antidotum na uprzedmiotowienie i ekonomizację osoby ludzkiej" (Hajduk 2017, 190). Ma ono charakter personalistyczny, który uwidacznia się we właściwym podejściu do człowieka chorego, cierpiącego i często zagubionego. Za model relacji kapelan-osoba chora należy uznać Chrystusa, który jest kluczem do zrozumienia człowieka. „Człowiek nie może siebie sam do końca zrozumieć bez Chrystusa. Nie może zrozumieć ani kim jest, ani jaka jest jego właściwa godność, ani jakie jest jego powołanie i ostateczne przeznaczenie" (Jan Paweł II 1979, 34). Tylko w Chrystusie człowiek poznaje, że jest osobą wolną, dynamiczną, kierującą się miłością, wezwaną do nowego życia. Jak zauważył Hajduk (2017, 190), „zgodnie z duchem personalizmu, łagodność pastoralna odwołuje się do zasady, iż to prawo służy osobie, a nie osoba prawu, a normy moralne nie są po to, aby ludzi ograniczać, lecz by ich prowadzić do doskonałości”.

Kapelani okazujący chorym miłosierdzie powinni pamiętać, że mają przed sobą konkretnego człowieka, w specyficznej sytuacji życiowej. Choroba jest stanem skłaniającym człowieka do refleksji - w swoim sumieniu stara się on rozeznać, czego Bóg od niego oczekuje w obliczu przeżywanego doświadcze- 
nia, a może zbliżającej się nieuchronnie śmierci czy kalectwa. Zaaplikowanie koncepcji personalistycznej do świata medycyny domaga się od kapelanów towarzyszenia chorym w ich zmaganiu się z chorobą, cierpieniem i lękiem oraz jest odpowiedzią na konkretne ich potrzeby (Babicz i Grabowicz 2012, 69-71). Punktem wyjścia takiego podejścia jest założenie, że chorzy nie są biernymi adresatami kościelnej posługi, ponieważ cierpiąc, uczestniczą $\mathrm{w}$ realizacji Bożego planu zbawienia świata. Chorych i cierpiących nie można uznać jedynie za przedmiot duszpasterskiego oddziaływania, lecz ważną cząstkę Kościoła, tj. wspólnoty w drodze.

Pastoralna troska Kościoła, której konkretnym przejawem powinna być adekwatna posługa kapelana, rozpoczyna się od zbliżenia się do osoby chorej i skutkuje przyjęciem postawy solidarności z nią. Powinno to doprowadzić do tworzenia w szpitalu przestrzeni wolnej od ubezwłasnowolniania czy instrumentalnego traktowania pacjentów. Podejście do każdego chorego z szacunkiem, uwzględniające jego odrębność, indywidualność oraz niepowtarzalność, jest zgodne z logiką miłosierdzia i sprzyja kształtowaniu środowiska przyjaznego pacjentowi. Jego przejawem będzie m.in. sposób sprawowania posługi sakramentalnej wobec pacjentów. Personalistyczne traktowanie chorego, w duchu benignitas pastoralis może uchronić kapelana od rutynowego udzielania sakramentu chorych, bezrefleksyjnego sprawowania sakramentu pojednania i pokuty czy rozdawania Komunii św. Praca wykonywana w duchu pastoralnej łagodności z pewnością będzie miała znaczący wpływ na lepszą jakość życia chorych przebywających w szpitalu.

W posłudze kapelana szpitalnego $\mathrm{w}$ duchu benignitas pastoralis ważne jest pedagogiczne podejście do pacjentów, zakładające konieczność ciągłego formowania człowieka ,poznającego, miłującego i czyniącego dobro moralne odpowiednio do etapów swego rozwoju" (Jan Paweł II 1979, 34). Zastosowanie w takiej sytuacji ma tzw. prawo stopniowości, zakładające, że każdy człowiek ma indywidualną drogę duchowego wzrostu i realizuje ją tylko w sobie właściwy sposób. Zgodnie z przywołanym prawem, pewnych duchowych procesów nie można na siłę wymuszać ani przyspieszać. W takim podejściu ujawnia się Boża pedagogia, charakteryzująca się cierpliwością, łagodnością i czułością, będąca znakiem respektu dla osobowej godności człowieka oraz szacunku dla jego podmiotowości i wolności. Pedagogia łagodności sprzyja propagowaniu wolności, „,która w chrześcijaństwie utożsamiana jest z możliwością dokonywania mądrych wyborów, prowadzących człowieka do osiągnięcia doskonałości i szczęścia" (Hajduk 2017, 191). Środowisko szpitala powinno stawać się w coraz większym stopniu miejscem wprowadzania w życie takiej właśnie pedagogii, w konsekwencji czego duchowni tam pracujący powinni podchodzić indywidualnie do każdego chorego, starając się dostrzec w nim niepowtarzalną godność i duchowe piękno. Cierpliwość w oczekiwaniu na duchowy wzrost 
chorego należy uznać za konkretny przejaw pastoralnej łagodności, która dla chorego będzie darem i przyniesie mu duchowe wytchnienie.

Według Hajduka $(2017,191)$, „łagodność, czułość i cierpliwość, czyli postawy typowe dla duszpasterstwa miłosierdzia, mają również właściwości terapeutyczne". Będąc wyrazem szacunku, respektowania wolności człowieka, zrozumienia dla jego niedoskonałości i popełnianych błędów, są niezbędne w pracy kapelana szpitalnego. Pomagają choremu pokonywać szereg lęków, odzyskiwać wiarę we własne możliwości w sytuacji obiektywnie trudnej, jaką jest choroba czy nadchodzący kres ziemskiego życia. Jak pisze Hajduk (2017, 191-192), „tagodność pastoralna w perspektywie wiary służy komunikacji miłości Boga, wstępującego w ludzką historię i w swoim Synu biorącego na siebie ludzkie słabości. Spotkanie z Chrystusem w posłudze Kościoła pozwala człowiekowi odnaleźć moc do pokonywania zła i zbliżania się ku świętości, która w chrześcijaństwie jest synonimem pełni zdrowia”. Kapelan, pełen taktu, dyskrecji, kultury, ale przede wszystkim głęboko wierzący i ufający Bogu, może oddziaływać terapeutycznie, tj. pomóc dostrzec w ludzkim życiu, cierpieniu, chorobie i śmierci szerszą perspektywę, a jednocześnie być „schronieniem dla duszy", nie tylko chorego, ale także członków jego rodziny oraz personelu medycznego. Choroba może się stać dla człowieka szczególną formą życiowej terapii i duchowego dojrzewania, swoistym darem.

$\mathrm{Z}$ powyższych racji duszpasterstwo miłosierdzia, przejawiające się w pastoralnej łagodności kapelana pracującego w szpitalu, ma duży potencjał ewangelizacyjny. Tym samym objawiana przez Kościół na zewnątrz dobroć i miłość Boga będzie przyciągać ludzi, zwłaszcza w czasie choroby i cierpienia poszukujących i potrzebujących bliskości, zatroskania i duchowego wsparcia. Każdy człowiek, ale szczególnie dotknięty cierpieniem, doświadczający bezinteresowności, zrozumie, że kapelanowi chodzi tylko o jego duchowe dobro, co może zbliżyć go do Boga. Otaczając szacunkiem i życzliwością wszystkich pacjentów, kapelani „wskazują na Chrystusa i Kościół, jako na żywe świadectwo prawdy i wolności, sprawiedliwości i pokoju" (Mszał Rzymski, V Modlitwa Eucharystyczna C). Taka „filozofia” podejścia duszpasterza do pacjenta, potwierdzona przez jego konkretne czyny, staje się tożsama z głoszeniem Ewangelii i jednocześnie zaproszeniem tych ludzi do uczestnictwa w życiu Kościoła (Hajduk 2017, 192).

Ewangelizacyjny wymiar benignitas pastoralis odnosi się także do członków rodzin osób chorych oraz szeroko rozumianego personelu ochrony zdrowia. Środowisko, w którym przychodzi dziś pracować księżom kapelanom, często odnosi się z dużym dystansem do kwestii religijnych oraz do Kościoła i jego kapłanów. Kontakt tych osób z kapelanem, który potrafi w duchu pastoralnej łagodności wyjść naprzeciw członkom najbliższej rodziny chorego czy personelu medycznego, w dalszej perspektywie może skłonić ich do refleksji 
prowadzącej do otwarcia się na sprawy duchowe, zmiany sposobu myślenia, a w konsekwencji do nawrócenia. Należy sobie uświadomić, że to właśnie łagodność i czułość Jego wyznawców prowadzi do spotkania z Chrystusem. Benignitas pastoralis kruszy zatwardziałe serca, a prawda o bezmiarze Bożego miłosierdzia ułatwia dostrzeżenie własnych słabości i grzechów. Nieosądzanie człowieka, okazywanie mu zrozumienia i towarzyszenie w drodze wpisuje się w dzieło ewangelizacyjne, w którym księża kapelani powinni mieć swój udział.

Kwestie łagodności pastoralnej porusza w swoim nauczaniu także papież Franciszek, wzywający Kościół do odnowy duszpasterskiej praktyki miłosierdzia w duchu łagodności pastoralnej. Powinna ona uwzględniać kondycję człowieka, głównie jego skłonność do grzechu. Papież zachęca wszystkich chrześcijan do ,pójścia drogą Jezusa poszukującego zagubionych grzeszników i okazywania miłosierdzia wszystkim ludziom, którzy tego pragną" (Franciszek 2016, 296). Papież wzywa wszystkich uczniów Chrystusa do zwrócenia się ku ludziom źle się mającym i poszukiwania ich „,na najróżniejszych peryferiach egzystencjalnych, które często dzisiejszy świat stwarza w sposób dramatyczny" (Franciszek 2015, 15). Otoczone nowoczesną aparaturą medyczną i pozbawione duchowego wsparcia i pomocy osoby chore często czują się zapomniane i nikomu niepotrzebne.

Głoszenie pacjentom Dobrej Nowiny o Bożym miłosierdziu jest równocześnie zaproszeniem ich do udziału w misterium, którym jest Kościół, przygarniający szczególnie człowieka błądzącego i grzesznego. Taki styl pracy duszpasterskiej wymaga jednak od duchownych odwagi, gdyż implikuje porzucenie egocentryzmu i okazywania wyższości wobec wiernych oraz rezygnację z bezpiecznego i wygodnego stylu życia. Zdaniem papieża Franciszka, tylko postawa oparta na łagodności pastoralnej może się stać czytelnym znakiem Bożego miłosierdzia i skłonić ludzi do poszukiwania i odnalezienia drogi powrotu do Ojca (Franciszek 2015, 12). Papież porównuje ograniczanie ewangelizacji do głoszenia i przekazywania konkretnych norm moralnych, bez głoszenia Dobrej Nowiny o Bożym miłosierdziu, do rzucania w wiernych kamieniami (Franciszek 2016, 49). Franciszek ostrzega, że takie traktowanie ludzi przeżywających trudności życiowe pozbawi ich możliwości dostrzegania w Kościele źródła ich osobistej nadziei.

Łagodność pastoralna w posłudze kapelana szpitalnego pracującego wśród chorych i ich rodzin oraz personelu medycznego powinna w konsekwencji doprowadzić go do zrozumienia stanu, w jakim się oni znaleźli. W centrum benignitas pastoralis powinno znaleźć się okazywanie współczucia ludzkim słabościom i unikanie surowych ocen, formułowanych, jak mówi papież Franciszek, w duchu bezdusznej, ,zimnej moralności rozwijanej przy biurku” (Franciszek 2016, 296). To właśnie łagodność pastoralna, jako znak miło- 
siernej miłości Boga, uzdalnia ludzi do pójścia za Jezusem, który jest Drogą, Prawdą i Życiem.

\section{Uwagi końcowe}

Człowiek otoczony miłością odczuwa ulgę, szczególnie w chwilach dla niego trudnych, związanych z chorobą i cierpieniem. Zaczyna wówczas rozumieć, że miłość jest doświadczeniem prawdy, pozwalającym zobaczyć rzeczywistość z innej perspektywy. Współczucie i troskę ze strony kapelana ułatwiają choremu przekonanie się, że miłość Boża jest wspaniałomyślnym darem i łaską (Franciszek 2013, 26). Nic nie jest w stanie mocniej poruszyć człowieka i skłonić do radykalnej zmiany życia aniżeli spotkanie z życzliwością i łaskawością Boga, widoczną w postawie kapłanów nacechowanej benignitas pastoralis. Tylko doświadczenie Bożej miłości może „nauczyć” człowieka prawdziwie kochać i być miłosiernym wobec bliźnich. Dla wszystkich duszpasterzy, a w szczególności dla pracujących w szpitalach, oznacza to konieczność zbliżenia się do drugiego człowieka w postawie czułości samego Boga, którego miłosierna miłość daje światu zbawienie.

Z powyższych analiz wynika, że łagodność pastoralna w pracy kapelana szpitalnego, w kontekście opieki duchowej nad pacjentem, jest postulatem jak najbardziej właściwym. Opieka duchowa nad pacjentem staje się dziś w Polsce naglącym problemem nie tylko medycznym, ale także pastoralnym. W świetle obecnej wiedzy uzasadnione wydaje się wezwanie do tworzenia w szpitalach, hospicjach i innych placówkach medycznych profesjonalnych zespołów opieki duchowej. Aby świadczyć zintegrowaną, profesjonalną opiekę duchową, wszyscy członkowie zespołu medycznego powinni mieć odpowiednie kompetencje w tym zakresie, natomiast kapelanów należałoby wyposażyć w umiejętność oceny i adekwatnego reagowania na różnorodne potrzeby duchowe, oczekiwania i nadzieje pacjentów, ich rodzin oraz członków zespołu medycznego.

\section{PASTORAL GENTLENESS IN THE WORK OF A HOSPITAL CHAPLAIN IN THE CONTEXT OF SPIRITUAL CARE FOR THE PATIENT}

\section{SUMMARY}

In the article the author reflects on the question of applying the principle of benignitas pastoralis (pastoral gentleness), known since antiquity, in the work of a hospital chaplain, especially in the context of the problem of spiritual care of the patient. At 
the beginning of the article, the very concept of spiritual care is introduced, then the pastoral care based on pastoral gentleness is explained, and in the final part, attention is drawn to the implications of benignitas pastoralis in the work of the hospital chaplain in terms of spiritual care for the patient.

Many of the qualities of pastoral gentleness can be applied explicitly to the service of the chaplain in the hospital, especially its personalistic character, pedagogical value, therapeutic effect and evangelical strength. We already know with scientific certainty that a good spiritual care is in the best interest of the patient. It is becoming increasingly clear that to achieve this goal, it is necessary to approach the patient with empathy and respect, to talk to him and to learn about his needs, fears, dreams and hopes. As part of such care, the chaplain's attitude based on benignitas pastoralis seems to be necessary today.

Keywords: pastoral gentleness, spiritual care, hospital chaplain

Słowa kluczowe: łagodność pastoralna, opieka duchowa, kapelan szpitalny

\section{BIBLIOGRAFIA}

Babicz, Agata i Sebastian Grabowicz. 2012. Duszpasterstwo w stylu św. Jana Bożego, Kraków: Prowincja Polska Zakonu Szpitalnego św. Jana Bożego.

Beida, Grzegorz i Jolanta Lewko i Agnieszka Kulak-Bejda. 2017. Postrzeganie roli kapelana szpitalnego w zespole terapeutycznym. Medycyna Paliatywna, 9(3),57-163. Poznań: TERMEDIA Wydawnictwo Medyczne.

Benedykt XVI. 2005. Encyklika O miłości chrześcijańskiej Deus caritas est.

Brożek, Beata et.al. 2018. Terapia wzmacniająca godność jako narzędzie odnajdywania nadziei i poczucia sensu u kresu życia chorych. Medycyna Praktyczna, 3, 122-124.

Franciszek. 2013. Encyklika O wierze Lumen fidei.

Franciszek. 2015. Bulla Ustanawiajaca nadzwyczajny Jubileusz Miłosierdzia Misericordiae vultus.

Franciszek. 2016. Adhortacja apostolska O miłości w rodzinie Amoris laetitia.

Hajduk, Ryszard. 2015. Powołani do bycia z Bogiem. Duchowy charakter działalności pastoralnej według Henriego J.M. Nouwena. W: In nomine Domini. Księga Pamiątkowa ku czci Księdza Biskupa Jana Styrny w 50. rocznicę posługi kapłańskiej, red. Stanisław Sojka, Stefan Ewertowski, Olsztyn-Elbląg,139-150. Olsztyn: Uniwersytet Mazursko-Warmiński.

Hajduk, Ryszard. 2017. Miłosierdzie duszpasterskie w tradycji kościelnej i w Amoris laetitia papieża Franciszka. Forum Teologiczne, XVIII,181-195.

Hajduk, Ryszard. 2018. Łagodność pastoralna, Kraków: Homo Dei.

Jan Paweł II. 1979. Homilia na Placu Zwycięstwa w Warszawie. Dostęp: 12.01.2020. https://zrodlo. krakow.pl/rocznik-2011/numer-18/czlowieka-nie-mozna-do-konca-zrozumiec-bez-chrystusa.

Jan Paweł II.1979. Adhortacja apostolska O zadaniach rodziny chrześcijańskiej w świecie wspótczesnym Familiaris consortio.

Kongregacja ds. Kultu Bożego i Dyscypliny Sakramentów. 2008. Mszał Rzymski.

Krajnik, Małgorzata. 2016. Komentarz. Medycyna Praktyczna, 5, 122-124.

Nouwen, Henri. 1993. Suche nach Einklang. Von der geistlichen Kraft der Erinnerung, Freiburg i. B.: Verlag Herder GmbH. 
Nouwen Henri i Paul McNeill i Dawid Morrison.1997. Compassion. A Reflection on the Christian Life, London: Darton, Longman and Todd.

Puchalski, Christine. 2006. Spiritual assessment in clinical practice. Psychiatr Ann, 36(3), 150-155.

Puchalski, Christine. 2013. Integrating spirituality into patient care: an essential element of person-centered care. Polskie Archiwum Medycyny Wewnętrznej, 123(9), 491-497.

Sobór Watykański II. 1965. Konstytucja dogmatyczna o Objawieniu Bożym Dei Verbum.

Szparkowska, Sylwia. 2013. Opieka duchowa nad pacjentem - zbędny luksus czy niezbędny element leczenia? Dostęp: 5.11.2019. https://www.mp.pl.

Vandenhoeck, Anne. 2013. Chaplains as specialists in spiritual care for patients in Europe. Polskie Archiwum Medycyny Wewnętrznej, 123(10), 552-557.

Vidal, Marciano. 1996. Carisma redentorista y propuesta moral. Ser redentorista hoy. Testimonios sobre el carisma, Roma: Armando Miranda.

Winter-Pfändler Urs i Morgenthaler Camille. 2011. Patients' satisfaction with health care chaplaincy and affecting factors: an exploratory study in the German part of Switzerland. J Health, Care Chaplain, 17(3-4), 146.

Andrzej Bohdanowicz - prof. UAM dr hab., Wydział Teologiczny Uniwersytetu im. Adama Mickiewicza w Poznaniu, abohdan@amu.edu.pl 